\title{
The Use of Peer Support on Adolescent Health Among Senior High School Students
}

\author{
Elly Dwi Wahyuni ${ }^{1}$, Junengsih ${ }^{2}$, Erma Yuliani ${ }^{3}$ \\ 1,2,3 Jakarta III Health Polytehcnique, Jl. Arteri Jorr Jatiwarna, Bekasi, Indonesia
}

\begin{tabular}{|c|c|}
\hline ARTICLE INFORMATION & A B S T RA C T \\
\hline $\begin{array}{l}\text { Article Trace } \\
\text { Submission: August, 14, } 2019 \\
\text { Final Revision: September 19, } 2019 \\
\text { Available online: October 26, } 2019 \\
\end{array}$ & \multirow{3}{*}{$\begin{array}{l}\text { Background: Problems related to adolescent reproductive behavior are } \\
\text { often rooted in a lack of information, understanding and awareness to } \\
\text { achieve reproductive health, so that impacts such as risky sexual } \\
\text { behavior in adolescents can arise; therefore, the use of peer supports is } \\
\text { very important. Objective: to describe the utilization of peer support of } \\
\text { the adolescents in SMA Suluh of South Jakarta in } 2019 \text {. Method: the } \\
\text { research type was descriptive quantitative with crosssectional design. } \\
\text { The population was all students in one senior high school with a sample } \\
\text { of } 100 \text { respondents collected through stratified random sampling. } \\
\text { Result: This study showed that most of the students had used peer } \\
\text { support ( } 66 \%) \text {, and small part of the respondents did not yet utilize peer } \\
\text { support }(34 \%) \text {. Most of the respondents who did peer support were } \\
\text { teenage girls ( } 72 \%) \text {, living with their parent ( } 68 \%) \text {, having good } \\
\text { knowledge }(66 \%) \text {, school support ( } 70.3 \%) \text {, and support from health } \\
\text { workers (67.8\%). Conclusion: Most of the respondents had } \\
\text { implemented peer support with support system from self-capacity, } \\
\text { family support and support from the school }\end{array}$} \\
\hline $\begin{array}{l}\text { Key Word: } \\
\text { : Peer support, Adolescentm Health }\end{array}$ & \\
\hline $\begin{array}{l}\text { Contact: } \\
\text { asiahmusthofawi@gmail.com }\end{array}$ & \\
\hline
\end{tabular}




\section{INTRODUCTION}

Peer counseling is a helping process that involves one-on-one interaction among members of a group, who have several things in common. In an academic setting, it usually refers to students helping their fellow students. Peer counseling should not be confused with peer support. The difference between the two is that the latter is more general (informal help; general information and advice given by and to peers), whereas peer counseling is a structured method (Peter van Kan, 1996).

UNICEF reports that there has been an alarming trend due to the increase in the number of teenage deaths aged 10-19 years as a result of HIV/AIDS worldwide, namely 71,000 teenagers in 2005 increasing to 110,000 in the year 2012 . (Winangsih, Kurniati, \& Duarsa, 2018).

Based on research on factors affecting the utilization of adolescent reproductive health services in Jayapura City, most of the respondents need adolescent reproductive health services $(90.1 \%)$ and only $9.9 \%$ of those do not need the services (Kristina, 2017).

Indonesian Government develops PKPR program in order to provide promotive, preventive, curative, and rehabilitative services that must be provided comprehensively in all places that will do youth services with PKPR approach. Some strategies that have been done are, among others, the provision of information and education, medical clinical services including supporting examination, counseling, education of healthy life skills, training of peer supports (Indonesia Ministry of Health, 2014)

Maryatun (2011) in Sarmin (2017) showed about the process of implementing peer supports through the Center for Adolescent/student information and counseling (PIK R/M) that, of 20 groups of $\mathrm{PIK} \mathrm{R} / \mathrm{M}, 16$ groups have empowered peer supports with both the impact of growth and positive changes in student behavior.

Based on a preliminary study on 13 teenagers in South Jakarta High School in January 2019 with a range of age 16-17 years, most teenagers did not know about peer supports, most also never accessed peer support, and most teenagers required peer-to-peer support services.

\section{RESEARCH METHODS}

This study used a type of quantitative descriptive research with cross sectional research design. The population of this study was the whole youth in South Jakarta High School in 2019 which amounted to 720 people. The number of samples obtained from the stratified random sampling technique formula was 100 samples. The technique of collecting the data used by the researcher was to fill the questionnaire directly by the respondent at the research site. Data was analyzed regarding the utilization of peer support services based on adolescents' characteristics (age, gender, religion, and residence status), based on adolescent knowledge, the need for counselor services, support, and support of the healthcare personnel.

\section{RESULTS AND DISCUSSION}

The number of respondents who participated in the study was adolescents. They had an age characteristic of 14-16 years (69\%) and 17-19 $(31 \%)$. The gender of respondents was $50 \%$ female and $50 \%$ male. Most of the respondents lived with their parents $(94 \%)$. The religion of respondent was Islam (87\%), Protestant (7\%) anda Chatolic (6\%).

Based on Bahasa Indonesia Dictionary (2008), utilization means utilizing. Utilization is a process, way or deed to use and utilize something that is around. Adolescents' service utilization by teenagers is a teenager who has leveraged counsellor services to be able to help troubleshoot his or her problems and avoid the negative influences that can be made by peers

Tabel 1. Distribution of peer to peer support utilization

\begin{tabular}{ccc}
\hline Peer support & n & \% \\
\hline Use acces & 66 & 66 \\
Not use acces & 34 & 34 \\
& 100 & 100 \\
\hline
\end{tabular}

Based on Table 1, of 100 respondents, 66 respondents $(66 \%)$ had used the peer support service and 34 respondents (34\%) who did not utilize the service. This was higher compared with the result of Kristina (2017) and Arie (2011). The location difference of these three researches also linked availability of information acces. 
Tabel 2. Frequently discussed topic in Peer Support

\begin{tabular}{ll}
\hline Topic & n \\
\hline Reproductive health & 15 \\
Drugs & 11 \\
Personal issues & 22 \\
Social Issues & 18 \\
\hline
\end{tabular}

Tabel 3. Respondent's reasoning to not use peer support

\begin{tabular}{lcc}
\hline Reason & $\mathbf{n}$ \\
\hline Do not have opinion & & 22 \\
Lazyness & 6 \\
Do need support & 2 \\
Too busy & 4 \\
\hline
\end{tabular}

Table 4. Service utilization of peer-to-peer support based on adolescent characteristics

\begin{tabular}{|c|c|c|c|c|c|c|}
\hline \multirow{3}{*}{ Characteristics } & \multicolumn{4}{|c|}{ Peer support } & \multicolumn{2}{|c|}{ Total } \\
\hline & \multicolumn{2}{|c|}{ Utilize } & \multicolumn{2}{|c|}{ Not utilize } & \multirow[b]{2}{*}{$\mathrm{n}$} & \multirow[b]{2}{*}{$\%$} \\
\hline & $\mathrm{n}$ & $\%$ & $\mathrm{n}$ & $\%$ & & \\
\hline \multicolumn{7}{|l|}{ Age } \\
\hline 14-16 year & 43 & 62,3 & 26 & 37,6 & 69 & 69 \\
\hline $17-19$ years & 23 & 74,1 & 8 & 25,8 & 31 & 31 \\
\hline \multicolumn{7}{|l|}{ Gender } \\
\hline Male & 30 & 60 & 20 & 40 & 50 & 50 \\
\hline Women & 36 & 72 & 14 & 28 & 50 & 50 \\
\hline \multicolumn{7}{|l|}{ Religion } \\
\hline Islam & 56 & 64,3 & 31 & 35,6 & 87 & 87 \\
\hline Protestant & 5 & 71,4 & 2 & 28,5 & 7 & 7 \\
\hline Khatolic & 5 & 83,3 & 1 & 16,6 & 6 & 6 \\
\hline \multicolumn{7}{|l|}{ Residential } \\
\hline Status & & & & & & \\
\hline $\begin{array}{l}\text { Not with parents } \\
\text { With parents }\end{array}$ & 64 & 68 & 30 & 31,9 & 94 & 94 \\
\hline \multicolumn{7}{|l|}{ Knowledge } \\
\hline Less & 1 & 100 & - & - & 1 & 1 \\
\hline Enough & 6 & 60 & 4 & 40 & 10 & 10 \\
\hline Good & 59 & 66,2 & 30 & 33,7 & 89 & 89 \\
\hline \multicolumn{7}{|l|}{ Peer suppor } \\
\hline need & 2 & & & 86,6 & & 15 \\
\hline $\begin{array}{l}\text { Yes } \\
\text { no }\end{array}$ & 64 & 75,2 & 21 & 24,7 & 85 & 85 \\
\hline \multicolumn{7}{|l|}{ School support } \\
\hline Yes & $\begin{array}{l}21 \\
45\end{array}$ & 58,5 & 15 & 41,6 & 36 & 36 \\
\hline No & & 70,3 & 19 & 29,6 & 64 & 64 \\
\hline \multicolumn{7}{|l|}{ Health provider } \\
\hline support & 7 & 53,8 & 6 & 46,1 & 13 & 6 \\
\hline $\begin{array}{l}\text { Yes } \\
\text { No }\end{array}$ & 59 & 67,8 & 28 & 32,1 & 87 & 94 \\
\hline
\end{tabular}

Age

According to Notoatmodjo (2012), age is a variable that is always considered in the research. The higher the age of a person, the more knowledge or knowledge is possessed because of a person's know-how from their own experience and the experience gained from others.

The research on the use of counseling service in South Jakarta High School obtained the results that most of the use of the peer support Service was a middle-aged youth (14-16 years) of 43 respondents. This is in accordance with the research conducted by Kristina (2017), about the factors that influence the utilization of the reproductive health services of adolescent in Jayapura City that based on the age, the respondents most utilizing the service were 15 year old teenagers.

At this age teenagers experience full physical maturation, among them the boys have had a wet dream and the woman has menstruation. So at this time teenagers are increasingly curious and finding out the various types of information related to the development of one of them through peer support.

\section{Gender}

Based on this research, it is known that those most utilizing the service of peer supports were women by $72 \%$, but there were still teenage boys who utilized the service by $60 \%$. These results were in accordance with the research (Arie 2011) on the acceptability and utilization of the information center and the adolescent reproductive health consultation at public high school students in Yogyakarta stating that most of the respondents most utilizing support services were female at $66.77 \%$.

This is because girls in psychology are more open to their peers, have a high sense of curiosity, more comfortable and not shy to tell and ask their fellow counselors. However, for male respondents it also did not close the possibility to be open and not shy to ask the counsellor so that there are still many male respondents who utilized the service.

\section{Religion}

The results of the research conducted shows that respondents had different religions. Respondents who were Moslem were by $64.3 \%$, Protestant and Khatolic were also largely responsible for utilizing peer-to-peer services. This is in accordance with the research conducted by Kristina (2017) on the factors affecting the utilization of the reproductive health services of teenagers in Jayapura that religion is one of the 
very important things in terms of teenagers behave.

All religions have taught the youth how to behave well to avoid the detrimental things such as unwanted pregnancies, drugs, and other adolescent problems. Religion is also referred to as religion derived from the Latin, religio rooted in the verb re-ligare which means "to bind again", meaning that someone is tying himself to God. Religion as a word can mean a person's guidelines to behave (Kristina, 2017).

\section{Residential Status}

The status of residence means the existence of respondents inside the house. The status of youth-supervised housing has the possibility of being able to take advantage of 2 times greater reproductive health services than teenagers who live unattended.

The results of the research conducted showed that respondents who used the service of a peer support were mostly teenagers who lived with the parents by $68.0 \%$ and $66.6 \%$ did not utilize the service counselor because they did not live with their parents. It was backed by the research conducted by Kristina (2017) on the factors affecting the utilization of the reproductive health care services in the city of Jayapura showing that teenagers who utilized health care were those who live in their parents' house.

This is because respondents feel the support and get attention from parents. Most teenagers also make parents a place to discuss personal issues, education, reproductive health and school activities. So, parents can encourage teenagers to utilize peer-to-peer services. Family function as the smallest unit in the environment plays an important role when teenagers make decisions and families can create a sense of comfort in teenagers.

\section{Knowledge}

According to (Notoatmodjo, 2010), knowledge is the result of human sensing, or the outcome of having a person know the object through its senses such as eyes, nose, and ears. Based on this research, those most utilizing the service were in a good knowledge by $66.2 \%$ but from the moderate knowledgeable, $60 \%$ utilized the peer support service.
The results of the authors' research are supported by Andersen theory which mentions that respondents with good knowledge better utilize the service in comparison to the less knowledge (Kristina, 2017). This is in accordance with the research conducted by (Sari, Musthofa, \& Widjanarko, 2017) about the relationship of adolescent participation in PKPR activities with knowledge and perception on reproductive health in a junior high school of the city of Semarang that $63.7 \%$ of respondents in this study had good knowledge.

\section{Needs}

Needs are basic and direct stimulus to use health care services. Youth in need of service have the possibility to be able to utilize reproductive health services 2 times greater than those of youth who do not need service (Kristina, 2017).

The results of this research, $75.2 \%$ needed the peer support services. This is in accordance with the research conducted by Arie (2011) on the acceptability and utilization of the Information Center and Adolescents' reproductive health consultation in public high school students in Yogyakarta, known that most of the respondents who use the counselling service were $57.05 \%$ teenagers.

Adolescents' need for information encourages teenagers to utilize peer-to-peer services. The information that teenagers need is mostly about reproductive health, social problems, personal problems, drugs, HIV/Aids, juvenile delinquency, free association, overcoming game addiction and other health information.

\section{Support from the school}

This research showed that $70.3 \%$ used the school support while $41.6 \%$ did not. This is in line with the research conducted by Winangsih, Kurniati, \& Duarsa (2018) about the predisposition factor, supporters and drivers of health-care utilization in South Kuta. It was known that those utilizing the service were mostly the ones who got support from the school.

Most of the support provided by the school included socialization of the activity of the counselling. The school members were also monitoring and evaluating the activities conducted by the peer who gave support 
services. This support is what drives most teenagers utilizing peer-to-peer service. As for the reason, some teenagers who do not utilize the service feel that the school does not support the service by having less complete facilities and infrastructure and provide less time for peer support activities.

\section{Healthcare Provider Support}

The results of this research showed that respondents who made use of peer support services were mostly respondents who got support from health officers by $67.8 \%$, while respondents who did not utilize were the ones who did not get support from health officers by $46.1 \%$.

This results supported research conducted by (Sari, Musthofa, \& Widjanarko, 2017) about the youth participation relationship in the health care activities of adolescents concerned with knowledge and perception on reproductive health in a secondary school of the city of Semarang that most of the respondents who utilized the service got support of the health officer by $50.5 \%$.

Healthcare personnel support is so important that it supports teenagers to utilize the service of peer supports. The support provided in the form of counseling, involving and training peer supports, the delivery of material by health personnel is clear and easy to understand, and the materials delivered according to the needs of teenagers.

\section{CONCLUSION}

The majority of respondents in South Jakarta High School have utilized peer support services. However, to improve the service, qualified peer supports require complete facilities and infrastructures such as a special counseling room to be comfortable and private. Schools also need to cooperate with health workers such as midwives and other health provider in order to help in fascilitation.

\section{BIBLIOGRAPHY}

Arie, A., Ismail, D., \& Emilia, O. 2011. Akseptabilitas dan Pemanfaatan Pusat Informasi dan Konsultasi Kesehatan Reproduksi Remaja pada Siswa Sekolah
Menengah Umum. Berita Kedokteran Mayarakat.

Azam, U. (2016). Bimbingan dan Konseling Perkembangan di Sekolah Teori dan Praktik. Yogyakarta: Deepublish.

Handayani, S., \& Rimawati, E. 2016. Pemanfaatan Layanan PKPR oleh Remaja di Wilayah Kerja Puskesmas Miroto Semarang. Jurnal Keperawatan dan Kesehatan Masyarakat.

Hendrawati, Heni. (2016). Analisis Potensi Tenaga Kerja Lokal Di Kawasan Bandara Internasional Jawa Barat (Bijb) Di Kecamatan Kertajati Kabupaten Majalengka Universitas Pendidikan Indonesia

| repository.upi.edu | perpustakaan.upi.ed u. 25-38.

Hidayat, A. A. 2009. Metode Penelitian Kebidanan dan Teknik Analisis Data. Jakarta: Salemba Medika.

Indonesian Minister of Health. 2014. Pedoman Standar Nasional Pelayanan Kesehatan Pedulu Remaja (PKPR). http://kesga.kemkes.go.id/images/pedoma $\mathrm{n} /$ PEDOMAN\%20STANDAR\%20NASI ONAL\%20PKPR.pdf

Kristina, Y. 2017. Faktor-faktor yang Mempengaruhi Pemanfaatan Pelayanan Kesehatan Reproduksi Remaja di Kota Jayapura. Jurnal Biologi Papua .

Notoatmodjo, s. (2010). Promosi Kesehatan Teori dan Aplikasi (edisi revisi ed.). Jakarta: Rineka Cipta.

Notoatmodjo, S. 2012. Metode Penelitian Kesehatan. Jakarta: Rineka Cipta.

Peter Van Kan, 1996. Peer counseling Tool and Trade a Work Document. https://www.peercounseling.org/index.php/peercounseling-tool-and-trade-aworkdocument-peter-van-kan

Sari, N. D., Musthofa, S. B., \& Widjanarko, B. 2017. Hubungan partisipasi remaja dalam kegiatan pelayanan kesehatan peduli remaja (PKPR) dengan pengetahuan dan persepsi mengenai 
Elly Dwi Wahyuni, Junengsih, Erma Yuliani

The Use Of Peer Support On Adolescent Health Among Senior High School Students

kesehatan reproduksi disekolah menengah pertama wilaah kerja puskesmas lebdosari. Jurnal Kesehatan Masyarakat .

Sarmin, Sarmin. 2017. Konselor Sebaya: Pemberdayaan Teman Sebaya dalam
Sekolah Guna Menanggulangi Pengaruh Negatif Lingkungan. Briliant: Jurnal Riset dan Konseptual. 2. 102. 10.28926/briliant.v2i1.30. 